\title{
Encouragement in Japan for good forest management
}

\section{Tokyo}

ThE International Tropical Timber Trade Organization (ITTO) based in Yokohama has made its first move towards encouraging improved forest management and sustainable use of tropical rainforests. Meanwhile, international environmental organizations have launched a campaign to halt destructive logging practices by Japan in Malaysia.

ITTO, a UN-sponsored council of 41 nations involved in the tropical timber trade, ended a five-day meeting on 20 November by approving a list of 12 projects on reafforestation, sustainable management and market trends with a total

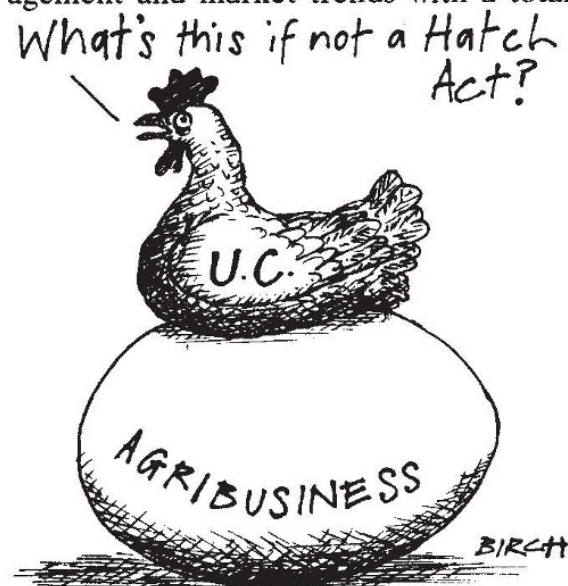

budget of $\$ 2.8$ million. Market trends for tropical timber trade in Europe, forest management in peninsular Malaysia, rehabilitation of previously logged forest in the Asia-Pacific region and sustainable management of an Amazon forest are among the projects approved.

The World Wildlife Fund provided $\$ 10,000$ for a $\$ 100,000$ project aimed at putting 100,000 hectares of Amazon forest in the state of Acre, Brazil, under sustainable management. But Dr Freezailah, executive director of ITTO, said there is still doubt among council members as to whether sustainable forest management is economically feasible on a large scale. Much will depend on major consumers of tropical timber, such as Japan.

Simultaneously with the ITTO meeting, Friends of the Earth International and the Japan Forest Action Network called on the Japanese timber trade to place a voluntary embargo on the importation of logs from Sarawak (Malaysia), to phase out importation of undressed logs, and to switch to importation of tropical hardwood that has been grown sustainably.

Japan is the world's leading importer of tropical wood. And 80 per cent of the imports come from Malaysia, nearly all of them in the form of unprocessed logs. Replanting and rehabilitation of defores- ted land in Malaysia is minimal, and according to the World Bank and FAO (Tropical Forest Action Plan) the forests are in a "critical condition" due to overexploitation and the forests of Sabah will be "commercially extinct" within less than five years.

Friends of the Earth intend to increase public awareness of the problem in Japan through, for example, signature-collecting campaigns. And the organization hopes to bring an end to wasteful practices, such as the use of tropical timber in disposable plywood panels for concrete moulding in Japan's huge construction industry.

Koy Thomson of Friends of the Earth is confident that "when the Japanese consumers learn of the quite inexcusable and appalling environmental and social destruction caused by their timber trade, they will follow the example set by UK consumers who are refusing to buy destructively produced tropical timber in order to encourage the market in sustainable products". But the issue is not drawing media attention in Japan, and probably will not do so unless foreign governments, in particular the US government, begin to exert pressure on Japan, as in the case of whaling.

\section{Too much agribusiness on California campus?}

\section{San Francisco}

IN a decision that could have a wide impact on US agricultural research, a California judge has ordered the University of California (UC) to tailor its agricultural research programmes to benefit small farmers.

The judge ruled that the Hatch Act, an 1887 law that provides research funds for the land-grant universities, requires that the research it supports must benefit family farmers. Land-grant universities received gifts of federal property from the government as a part of their endowment. The judge's interpretation of the Hatch Act could fuel challenges to agricultural research in other states.

UC plans to appeal against the ruling, and argues that such limitation on the direction of research violates academic freedom. Hatch Act funds constitute less than 4 per cent of UC's annual $\$ 116.5$ million budget for agricultural research, but the money is spread over nearly 40 per cent of the research projects.

The lawsuit, filed in 1979 by a group of

\section{Serron sacked}

\section{Paris}

THE sacking last week of Dr Bernard Serrou, head of the French National health education committee (CFES), only a year after his appontment by Health Minister Michèle Barzach, has been connected by some French newspapers with the 'disappearance' of millions of information leaflets about AIDS (acquired immune deficiency syndrome) due to have been distributed throughout France. A confidential report presented to Barzach by IGAS (the general inspectorate of social affairs) is thought to contain several examples of mismanagement at CFES since Serrou was appointed. small family farmers and farm workers, grew out of dismay over the mechanized tomato picker, developed in the early 1960 s by agricultural engineers at UC. More than 30,000 farm workers lost their jobs as a result of the introduction of the tomato harvester in California in the early 1970s, says Bill Hoerger, attorney for the plaintiffs, and the number of tomato farmers in the state dropped from 4,000 to 490 , although acreage planted in tomatoes doubled.

Concerned that UC was conducting agricultural research that primarily benefited larger farming corporations, the group filed a lawsuit claiming a variety of inappropriate relationships between UC employees and agribusiness companies. All charges but the Hatch Act violation were eventually dropped.

The plaintiffs were opposed to mechanization research, as well as to studies, among others, designed to produce uniformly ripening crops, a first step, they argued, toward the development of machines to harvest those crops. UC representatives argue that uniformly ripening crops would be beneficial and work-saving for all farmers, not just the giants.

UC attorney Christine Helwick says the judge did not decide that mechanization research hurts family farms, but merely ordered the university to evaluate the effect of its research on those farms. Helwick says UC research projects do keep the small farmer in mind, and adds that the California Grange, an organization of small farmers, entered the suit on the side of the university.

The university's opponents feel, however, that if UC properly evaluates the social and economic effects of its projects, it will be compelled to shift its research emphasis towards projects designed specifically to help family farmers.

Marcia Barinaga 